\title{
KETAHANAN GENETIK BERBAGAI KLON KARET INTRODUKSI TERHADAP PENYAKIT GUGUR DAUN
}

\author{
Genetic Resistance of the Introduced Rubber Clones to Leaf Fall Diseases
}

\author{
AIDI-DASLIN \\ Balai Penelitian Sungei Putih, Pusat Penelitian Karet \\ email : aididaslin@yahoo.com
}

Diterima tanggal 25 April 2013 / Disetujui tanggal 15 Mei 2013

\begin{abstract}
Corynespora cassiicola, Colletotrichum gloeosporioides and Oidium heveae leaf fall diseases on rubber plant are major disease causing reduction estate productivity significantly. Many cases of the disease attack have been found widely in natural rubber producing countries such as Indonesia, Malaysia, Thailand, Sri Lanka, India and some other countries in Africa. Field and laboratory studies using leaf disc method were conducted to know the resistance level of some introduction clones to leaf fall diseases of rubber. The research was arranged in a completely randomized design with three replications and twenty treatments with of clones. The tested of introduced clones consisted of clones from Malaysia (PB 260, PB 217, PB 254, PB 312, PB 314, $P B$ 330, PB 340, PB 350, PB 359, PB 366, RRIM 901, RRIM 908, RRIM 911, RRIM 921, RRIM 937), Sri Lanka (RRIC 100, RRIC 102, RRIC 110), and India (RRII 105, RRII 176). The results showed that there were significant differences of clones resistance to pathogens of $\mathrm{C}$. cassiicola, $\mathrm{C}$. gloeosporioides and $\mathrm{O}$. heveae. The clone resistance level to C. gloeosporioides was classified as resistant (RRIC 100), moderately resistant (PB 254, PB 260, PB 312, PB 314, PB 340, PB 366, RRIM 91 1, RRIM 921, RRIC 102), moderate (PB 330, PB 350, PB 359, RRIM 901, RRIM 908, RRIC 110, RRII 105, RRII 176), and moderately susceptible (PB 217, RRIM 937). It was noted that no resistant clones to $\mathrm{O}$. heveae, while the moderately resistant clone were $P B 260, P B 217$, $P B$ 254, PB 312, PB 314, PB 350, PB 359, RRIM 908, RRIM 911, RRIM 921, RRIM 937, RRIC 100, RRIC 110, RRII 105, RRII 176, the moderate clones were PB 330, PB 366, RRIM 901, RRIC 102 and the moderately susceptible clone was $P B$ 340. The clones resistance level to $\mathrm{C}$. cassiicola was classified as resistant were $P B 260$ and RRIC 100, moderately resistant $(P B$ 217, $P B$ 254, $P B$ 312, $P B$ 314, PB 330, PB 340, PB 350, PB 366, RRIM 901, RRIM 908, RRIM 921, RRIM 937, RRIC 102, RRIC 110, RRII 105, RRII 176) and moderate (PB 359, RRIM 911). The resistant clones could be used in
\end{abstract}

rubber breeding program to produce high latex yielding rubber clones and resistant to leaf fall diseases.

Keywords : Hevea brasiliensis, clone resistance, Corynespora cassicola, Colletotrichum gloeosporioides, Oidium heveae

Abstrak
Penyakit gugur daun Corynespora
cassiicola, Colletotrichum gloeosporioides dan
Oidium heveae pada karet merupakan penyakit
utama yang secara signifikan menurunkan
produktivitas kebun. Serangan yang luas
penyakit gugur daun tersebut banyak terjadi di
berbagai negara penghasil karet alam seperti
Indonesia, Malaysia, Thailand, Sri Langka, India
dan beberapa negara lain di Afrika. Penelitian
lapangan dan laboratorium dengan metode uji
cakram dilakukan untuk mengetahui tingkat
resistensi beberapa klon introduksi terhadap
penyakit gugur daun karet, menggunakan
rancangan acak lengkap, tiga ulangan dan 20
perlakuan (klon). Klon introduksi yang diuji
terdiri dari klon asal Malaysia PB 260, PB 217, PB
254, PB 312, PB 314, PB 330, PB 340, PB 350, PB
359, PB 366, RRIM 901, RRIM 908, RRIM 911,
RRIM 921, RRIM 937, asal Sri Langka RRIC 100,
RRIC 102, RRIC 110, dan asal India RRII 105, RRII
176. Hasil penelitian menunjukkan adanya
perbedaan resistensi klon yang diuji terhadap
patogen dari C. cassiicola, C. gloeosporioides dan
O. heveae. Klon yang tergolong resisten terhadap
C. gloeosporioides adalah RRIC 100, moderat
resisten PB 254, PB 260, PB 312, PB 314, PB 340,
PB 366, RRIM 911, RRIM 921, RRIC 102, moderat
PB 330, PB 350, PB 359, RRIM 901, RRIM 908,
RRIC 110, RRII 105, RRII 176, dan moderat
rentan PB 217, RRIM 937. Tidak ada klon yang
diuji tergolong resisten terhadap O. heveae,
sedangkan yang tergolong moderat resisten
adalah PB 260, PB 217, PB 254, PB 312, PB 314,
PB 350, PB 359, RRIM 908, RRIM 911, RRIM


921,RRIM 937, RRIC 100, RRIC 110, RRII 105, RRII 176, moderat PB 330, PB 366, RRIM 901, RRIC 102 dan moderat rentan PB 340. Klon yang tergolong resisten terhadap $C$. cassiicola adalah PB 260 dan RRIC 100, moderat resisten PB 217, PB 254, PB 312, PB 314, PB 330, PB 340, PB 350, PB 366, RRIM 901, RRIM 908, RRIM 921, RRIM 937, RRIC 102, RRIC 110, RRII 105, RRII 176 dan moderat PB 359, RRIM 911. Klon-klon yang resisten dapat dikembangkan dalam program pemuliaan karet untuk merakit klon unggul penghasil lateks tinggi dan tahan penyakit gugur daun.

Kata kunci : Hevea brasiliensis, resistensi klon, Corynespora cassiicola, Colletotrichum gloeosporioides, Oidium heveae

\section{PENDAHULUAN}

Penyakit gugur daun utama pada tanaman karet antara lain disebabkan oleh jamur Colletotrichum gloeosporioides, Oidium heveae dan Corynespora cassiicola. Ketiga penyakit daun tersebut merupakan penyakit penting karena dapat menyerang tanaman di pembibitan, tanaman muda, tanaman menghasilkan maupun di kebun kayu okulasi/entres. Pada tanaman menghasilkan, penyakit ini dapat merugikan karena daun-daun muda berguguran, yang mengakibatkan pertumbuhan tanaman terhambat, produksi lateks menurun bahkan mengakibatkan kematian tanaman.

Pada pertanaman karet di lapangan serangan C. gloeosporioides mengakibatkan gugurnya daun-daun muda sehingga tajuk tanaman tipis, perkembangan lilit batang terhambat dan tertundanya matang sadap (Pawirosoemardjo et al., 1998). Serangan Oidium mengakibatkan daun-daun muda yang baru terbentuk menjadi hitam dan akhirnya gugur, yang juga diikuti gugurnya tangkai daun, sedangkan serangan penyakit gugur daun $C$. cassiicola mengakibatkan gugurnya daun karet terus menerus sepanjang tahun karena dapat menyerang daun muda maupun tua, sehingga tanaman tidak dapat berproduksi dan lambat laun mengalami kematian (Situmorang et al., 1996).

Penyakit C. gloeosporioides menimbulkan epidemi pada tahun 1974 dan 1975 di Jawa, 1976 di Sumatera Utara dan 1989 di Kalimantan Barat dengan mengakibatkan penurunan produksi 7 - 45\%, tergantung dari intensitas serangan (Pawirosoemardjo dan Suryaningtyas, 2008). Epidemi penyakit timbul karena 1). Terjadi penyimpangan pola iklim dari yang normal, yaitu kemarau panjang yang diikuti musim hujan sepanjang tahun, 2). Kondisi tanaman karet yang lemah karena kurang perawatan, dan 3). Ditanamnya klon-klon yang tergolong rentan, seperti LCB 479, PR 228, PR 225, PR 300, PR 303, PR 305 dan GT 1 (Pawirosoemardjo, 2004).

Penyakit gugur daun C. cassiicola menimbulkan epidemi pada tahun 1980 dan 1990 dengan mengakibatkan penurunan produksi 30 - 40\%. Hal yang sama dilaporkan adanya kerugian produksi yang disebabkan penyakit $O$. heveae di beberapa perkebunan, ditaksir 30 - 40\% (Anggreani, 1975). Penyakit C. Cassiicola dilaporkan di India pada tahun 1958, kemudian di Malaysia pada tahun 1960 (Ramakrishnan dan Pillay, 1961; Newsam, 1961). Penyakit menyebar pada tahun 1980 di Indonesia, Sri Langka, Malaysia, dan Thailand pada klon rentan RRIC 103, RRIM 725, KRS 21, PPN 2058, PPN 2444, dan PPN 2447 (Mathew, 2006).

Tahun 1980 seluas 1.125 ha klon karet rentan seperti RRIC 103, KRS 21, RRIM 725, PPN 2058, PPN 2444 dan PPN 2447 di perkebunan karet Indonesia, dan 4.235 ha klon RRIC 103, RRIC 104, Tjir 1 dan RRIM 725 di Sri Lanka mengalami kerusakan berat (Soepena, 1983). Tahun 1988 dilaporkan beberapa klon karet seperti RRIC 103, KRS 21, dan RRIM 725 terserang berat di Malaysia (Chee, 1988) dan di Thailand serangan patogen mulai terjadi pada tahun 1985 pada klon karet RRIC 103 (Kajornchaiakul, 1987 cit. Pawirosoemardjo dan Heru, 2008).

Sejauh ini metode pengendalian yang diterapkan untuk mengendalikan penyakit gugur daun adalah secara kimiawi dengan menggunakan berbagai jenis fungisida. Pengendalian secara kimiawi memerlukan biaya yang mahal dan juga tingkat pencemaran lingkungan yang tinggi. Penggunaan klon karet unggul yang resisten merupakan salah satu strategi pengendalian yang murah dan ramah lingkungan untuk mencegah epidemi dan kerusakan yang ditimbulkan oleh penyakit gugur daun. Di 
Indonesia, perakitan klon unggul baru penghasil lateks tinggi dan tahan penyakit gugur daun, menjadi program utama dalam pemuliaan karet dengan memanfaatkan berbagai klon tahan penyakit sebagai tetua persilangan. Tersedianya berbagai klon introduksi merupakan sumber keanekaragaman genetik (plasma nutfah) karet yang sangat bermanfaat untuk digunakan dalam persilangan buatan. Tetua yang dipilih adalah klon-klon tahan penyakit dan klon produksi tinggi yang digunakan dalam program persilangan secara luas dengan teknik resiprocal cross maupun back cross.

Interaksi genotipe dan lingkungan memberikan pengaruh yang nyata terhadap kinerja klon (Aidi-Daslin dan Sayurandi, 2006). Diperlukan klon yang spesifik lokasi, khususnya klon resisten penyakit gugur daun untuk pengembangan penanaman karet ke wilayah endemi penyakit maupun beberapa daerah sub-optimal (daerah basah) yang sangat berpotensi munculnya gangguan penyakit gugur daun. Klon-klon produksi tinggi dan tahan penyakit pada daerah tersebut, akan menjamin produktivitas yang stabil selama siklus ekonomi karet yang lamanya kurang lebih 25 tahun (Aidi Daslin et al., 2009). Dalam artikel ini disampaikan hasil penelitian uji resistensi berbagai klon karet introduksi terhadap penyakit gugur daun Colletotrichum gloeosporioides, Oidium heveae dan Corynespora cassiicola.

\section{BAHAN DAN METODE}

Penelitian dilaksanakan di laboratorium proteksi dan kebun percobaan Balai Penelitian Sungei Putih, Galang, Deli Serdang, Sumatera Utara, dengan menggunakan rancangan acak lengkap, tiga ulangan dan 20 perlakuan (klon). Sebanyak 20 klon karet introduksi yang diuji terdiri atas PB 260,PB 217,PB 254,PB 312, PB 314, $\mathrm{PB} \quad 330, \mathrm{~PB} \quad 340, \mathrm{~PB} \quad 350, \mathrm{~PB} \quad 359, \mathrm{~PB}$ 366,RRIM 901,RRIM 908,RRIM 911,RRIM 921,RRIM 937, RRIC 100,RRIC 102, RRIC 110, RRII 105 dan RRII 176. Asal dan tetua setiap klon disajikan pada Tabel 1.

Tabel 1. Asal dan tetua klon karet introduksi yang diuji

Table 1. Source and parentage of tested introduced rubber clones

\begin{tabular}{|c|c|c|c|}
\hline No & $\begin{array}{l}\text { Klon } \\
\text { Clones }\end{array}$ & $\begin{array}{c}\text { Asal klon } \\
\text { Source of clones }\end{array}$ & $\begin{array}{c}\text { Tetua } \\
\text { Parentage }\end{array}$ \\
\hline 1. & PB 260 & Prang Besar, Malaysia & PB 5/51 x PB 49 \\
\hline 2 . & PB 217 & Prang Besar, Malaysia & PB 5/51 x PB 6/69 \\
\hline 3. & PB 254 & Prang Besar, Malaysia & PB 5/51 x PB S.78 \\
\hline 4. & PB 312 & Prang Besar, Malaysia & RRIM $600 \times$ PB 235 \\
\hline 5. & PB 314 & Prang Besar, Malaysia & RRIM $600 \times$ PB 235 \\
\hline 6. & PB 330 & Prang Besar, Malaysia & $\mathrm{PB} 5 / 51 \times \mathrm{PB} 32 / 36$ \\
\hline 7. & PB 340 & Prang Besar, Malaysia & PB $235 \times$ PR 107 \\
\hline 8. & PB 350 & Prang Besar, Malaysia & RRIM $600 \times$ PB 235 \\
\hline 9. & PB 359 & Prang Besar, Malaysia & PB 28/59 x PR 107 \\
\hline 10 . & PB 366 & Prang Besar, Malaysia & RRIM 600 x PB 202 \\
\hline 11. & RRIM 901 & Rubber Research Institute of Malaysia & PB 5/51 x RRIM 600 \\
\hline 12 . & RRIM 908 & Rubber Research Institute of Malaysia & PB 5/51 x RRIM 623 \\
\hline 13. & RRIM 911 & Rubber Research Institute of Malaysia & PB 5/51 x RRIM 623 \\
\hline 14. & RRIM 921 & Rubber Research Institute of Malaysia & PB 5/51 x FORD 351 \\
\hline 15 . & RRIM 937 & Rubber Research Institute of Malaysia & PB 5/51 x RRIM 703 \\
\hline 16. & RRIC 100 & Rubber Research Institute of Ceylon & RRIC 52 X PB 85 \\
\hline 17. & RRIC 102 & Rubber Research Institute of Ceylon & RRIC $52 \times$ RRIC 7 \\
\hline 18. & RRIC 110 & Rubber Research Institute of Ceylon & LCB 1320 x RRIC 7 \\
\hline 19. & RRII 105 & Rubber Research Institute of India & Tjir 1 x Gl 1 \\
\hline 20. & RRII 176 & Rubber Research Institute of India & Mil 3/2 x PB 5/60 \\
\hline
\end{tabular}

Sumber (Source) : Othman et al., 1996). 
Teknik inokulasi penyakit Colletotrichum gloeosporioides dan Corynespora cassiicola menggunakan metode cakram daun. Sampel daun diambil dari lapangan yaitu daun muda umur 20 hari, kemudian disterilisasi dengan Chlorox 0,1\%. Setiap daun dari klon karet dilubangi dengan alat pelubang gabus (cork borer) sehingga terbentuk cakram daun dengan diameter 2 $\mathrm{cm}$. Cakram daun direndam dalam suspensi patogen dengan kerapatan $4 \times 10^{4}$ konidia $/ \mathrm{ml}$ selama 2 menit, kemudian diletakkan ke dalam cawan petri yang sudah dilapisi dengan kertas saring lembab. Setiap cawan diletakkan 10 cakram daun yang disusun secara acak, kemudian dimasukkan ke dalam inkubator pada suhu $28^{\circ} \mathrm{C}$ dengan $\mathrm{Rh}$ $89 \%$. Pengamatan dilakukan setiap dua hari sekali, selama 6 hsi (hari setelah inokulasi). Nilai skala bercak daun ditentukan seperti tertera pada Tabel 2. Untuk penyakit Oidium hevea dilakukan pengamatan langsung terhadap sampel daun dari lapangan, dengan nilai skala bercak daun seperti tertera pada Tabel 3 .

Intensitas serangan penyakit gugur daun dihitung berdasarkan rumus yang dikembangkan Pawirosoemardjo(1999) sebagai berikut :

$$
\mathrm{I}=\frac{\sum(\mathrm{nxv})}{Z \times N} \times 100 \%
$$

dimana:

I : intensitas serangan

$\mathrm{n}$ : jumlah daun tiap kategori serangan

$\mathrm{v}$ : nilai skala dari setiap kategori serangan

$Z$ : nilai skala tertinggi dari kategori serangan

$\mathrm{N}$ : jumlah daun yang diamati

Penilaian kualitatif ketahanan klon terhadap serangan penyakit gugur daun ditentukan berdasarkan nilai intensitas serangan, dengan kriteria sebagai berikut :
Resisten
: $0-20 \%$
Moderat resisten $\quad: 21-40 \%$
Moderat
Moderat rentan $\quad: 61-80 \%$
Rentan : $81-100 \%$

\section{HASIL DAN PEMBAHASAN}

\section{Intensitas Serangan Penyakit}

Rataan intensitas serangan penyakit gugur daun Colletotrichum gloeosporioides,

Tabel 2. Nilai bercak untuk penyakit C.gloeosporioides dan C.cassiicola di laboratorium Table 2. Value of spots of C.gloeosporioides and C.cassiicola in laboratory.

\begin{tabular}{cl}
\hline $\begin{array}{c}\text { Nilai } \\
\text { Score }\end{array}$ & \multicolumn{1}{c}{$\begin{array}{c}\text { Keterangan } \\
\text { Remarks }\end{array}$} \\
\hline 0 & Tidak terdapat bercak pada daun \\
1 & Terdapat bercak $<1 / 4$ bagian pada daun \\
2 & Terdapat bercak $1 / 4-1 / 2$ bagian pada daun \\
3 & Terdapat bercak $>1 / 2-3 / 4$ bagian pada daun \\
4 & Terdapat bercak $>3 / 4$ bagian pada daun \\
\hline
\end{tabular}

Tabel 3. Nilai bercak untuk penyakit Oidium heveae di lapangan

Table 3. Value of spot of Oidium heveae in laboratory

\begin{tabular}{cl}
\hline Nilai & \multicolumn{1}{c}{$\begin{array}{c}\text { Keterangan } \\
\text { Remarks }\end{array}$} \\
\hline 0 & Tidak terdapat bercak pada daun \\
1 & terdapat bercak $1 / 16$ bagian pada daun \\
2 & terdapat bercak $1 / 8$ bagian pada daun \\
3 & terdapat bercak $1 / 4$ bagian pada daun \\
4 & terdapat bercak $1 / 2$ bagian pada daun \\
5 & terdapat bercak $>1 / 2$ bagian \\
6 & terdapat bercak pada seluruh permukaan daun \\
\hline
\end{tabular}


Oidium heveae dan Corynespora cassiicola dari dua puluh klon karet introduksi yang diuji, dapat dilihat pada Tabel 4. Hasil analisis pengujian resistensi menunjukkan intensitas serangan yang berbeda nyata diantara klon yaitu untuk C. gloeosporioides berkisar antara 16,67-70\%, dengan tingkat intensitas serangan terendah terdapat pada klon RRIC $100 \quad(16,67 \%)$ dan serangan tertinggi terdapat pada klon RRIM 937 $(70 \%)$. Intensitas serangan $O$. heveae berkisar $24-64 \%$, yang terendah terdapat pada klon RRII 105 (24\%) dan tertinggi terdapat pada klon PB 340 (64\%). Intensitas serangan jamur C. cassiicola bervariasi antara 10,00 - 43,33\%, dengan serangan terendah terdapat pada klon PB 260 dan RRIC 100 masing-masing $10,00 \%$ dan $10,83 \%$ dan tertinggi pada klon PB 359 dan RRIM 911 dengan intensitas serangan $43,33 \%$.
Respon ketahanan klon karet terhadap ketiga penyakit menunjukkan serangan penyakit gugur daun C. gloeosporioides memiliki patogenitas tertinggi dibanding dengan penyakit daun lainnya (Gambar 1). Hal ini disebabkan epidemi penyakit yang cukup luas dan fakta di lapangan memperlihatkan hampir semua klon terkena infeksi terutama pada kondisi lingkungan yang kondusif untuk perkembangan penyakit, sehingga karet menjadi tanaman inang yang cocok untuk C. gloeosporioides.

Perbedaan tingkat ketahanan yang ditunjukkan masing-masing klon karet introduksi yang diuji disebabkan karena adanya perbedaan ketahanan gen diantara klon. Terjadinya perubahan ketahanan klon dari tahun ke tahun dapat disebabkan perubahan ras fisiologis pada patogen. Klon karet yang pada awalnya tergolong resisten, beberapa lama kemudian berubah menjadi rentan karena serangan ras baru patogen.

Tabel 4. Nilai intensitas serangan penyakit gugur daun terhadap klon karet yang diuji Table 4. Attack intensity rate of leaf fall diseases on tested rubber clones

\begin{tabular}{|c|c|c|c|}
\hline \multirow{3}{*}{$\begin{array}{c}\text { Klon } \\
\text { Clones }\end{array}$} & \multicolumn{3}{|c|}{ Rataan intensitas serangan (\%) } \\
\hline & \multicolumn{3}{|c|}{ Average of attack intensity (\%) } \\
\hline & C. gloeosporioides & O. heveae & C. cassiicola \\
\hline PB 260 & $25,00 \mathrm{abc}$ & $36,00 \mathrm{ab}$ & $10,00 \mathrm{a}$ \\
\hline PB 217 & $65,00 \mathrm{gh}$ & $40,00 \mathrm{ab}$ & $34,50 \mathrm{bc}$ \\
\hline PB 254 & $21,67 \mathrm{ab}$ & $37,00 \mathrm{ab}$ & $32,50 \mathrm{bc}$ \\
\hline PB 312 & 38,33 cde & $27,00 \mathrm{a}$ & $37,50 \mathrm{a}$ \\
\hline PB 314 & $30,00 \mathrm{abcd}$ & $33,00 \mathrm{ab}$ & $39,17 \mathrm{bc}$ \\
\hline PB 330 & 50,00 efg & $52,00 \mathrm{ab}$ & $37,50 \mathrm{bc}$ \\
\hline PB 340 & 33,33 bcde & $64,00 \mathrm{~b}$ & $33,33 \mathrm{bc}$ \\
\hline PB 350 & 50,83 efg & $38,00 \mathrm{ab}$ & $33,17 \mathrm{bc}$ \\
\hline PB 359 & 51,67 efg & $26,00 \mathrm{a}$ & $43,33 \mathrm{c}$ \\
\hline PB 366 & 35,00 bcde & $54,00 \mathrm{ab}$ & $35,00 \mathrm{bc}$ \\
\hline RRIM 901 & $51,67 \mathrm{efg}$ & $43,00 \mathrm{ab}$ & $33,33 \mathrm{bc}$ \\
\hline RRIM 908 & 49,17 efg & $26,00 \mathrm{a}$ & $30,00 \mathrm{bc}$ \\
\hline RRIM 911 & 37,50 cde & $39,00 \mathrm{ab}$ & $43,33 \mathrm{c}$ \\
\hline RRIM 921 & 34,17 bcde & $40,00 \mathrm{ab}$ & $33,33 \mathrm{bc}$ \\
\hline RRIM 937 & $70,00 \mathrm{~h}$ & $30,00 \mathrm{ab}$ & $26,67 \mathrm{~b}$ \\
\hline RRIC 100 & $16,67 \mathrm{a}$ & $33,00 \mathrm{ab}$ & $10,83 \mathrm{a}$ \\
\hline RRIC 102 & 37,50 cde & $45,00 \mathrm{ab}$ & $26,67 \mathrm{~b}$ \\
\hline RRIC 110 & $58,33 \mathrm{fgh}$ & $36,00 \mathrm{ab}$ & $33,33 \mathrm{bc}$ \\
\hline RRII 105 & 48,33 efg & $24,00 \mathrm{a}$ & $35,83 \mathrm{bc}$ \\
\hline RRII 176 & 44,17 def & $34,00 \mathrm{ab}$ & $33,33 \mathrm{bc}$ \\
\hline
\end{tabular}

Angka yang diikuti oleh huruf yang sama pada kolom yang sama, tidak berbeda nyata pada taraf uji 0,01 (Figures followed by the same letter in the same column are not significantly different at 0,01). 


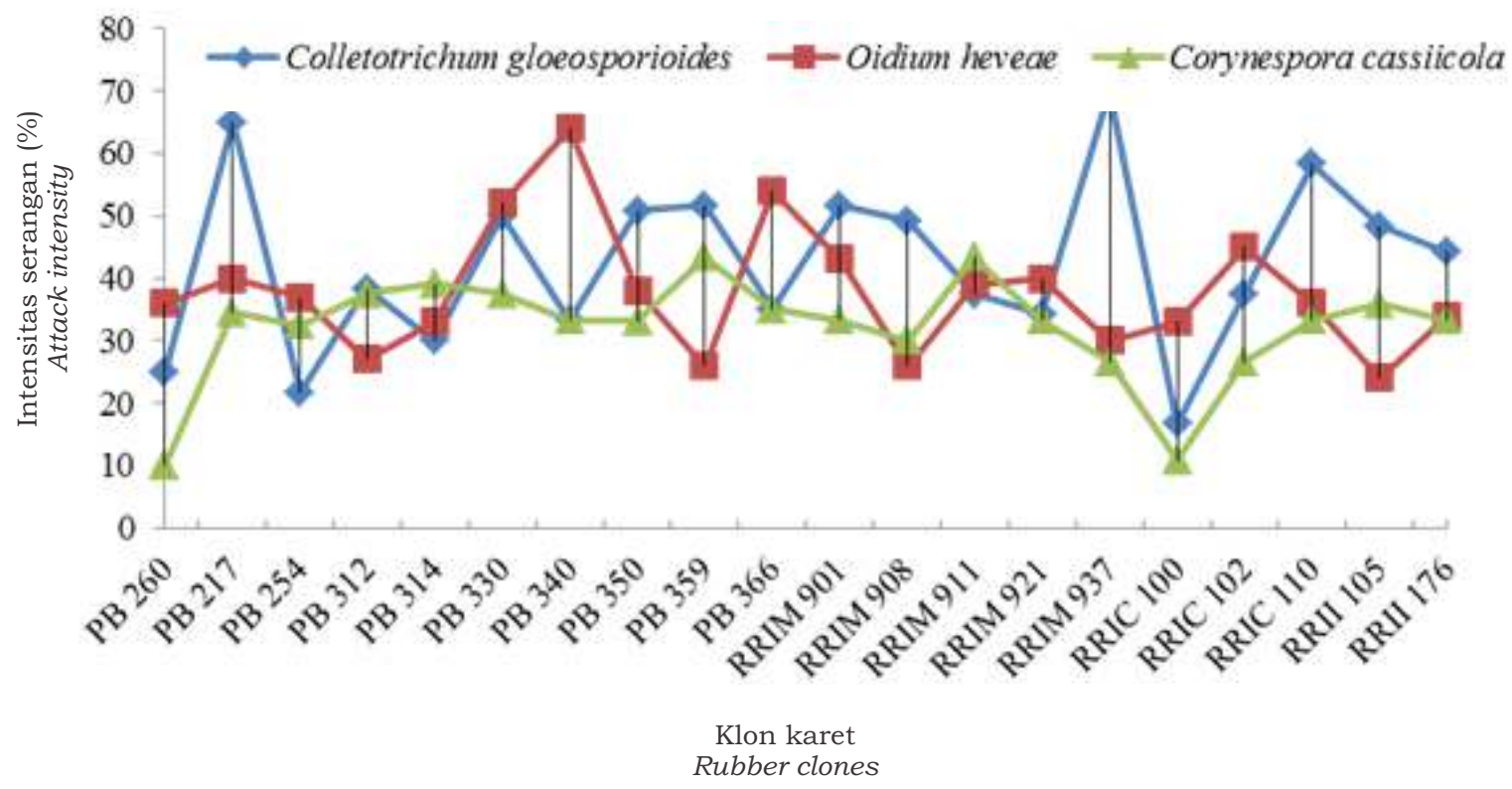

Gambar 1. Hubungan antara intensitas penyakit gugur daun dan klon introduksi Figure 1. Relationship between intensity of leaffall diseases and introduced clones

Dari data pengamatan memperlihatkan, semua klon karet mempunyai peluang terinfeksi patogen, tetapi tingkat kerusakan yang timbul berbeda antara klon yang satu dengan yang lain. Patogen menyebabkan penyakit pada tanaman dengan cara melemahkan inang yaitu menyerap makanan secara terus menerus dari sel inang, menghentikan dan mengganggu metabolisme sel inang dengan toksin, enzim atau zat pengatur tumbuh yang disekresikannya, menghambat transportasi makanan, hara mineral dan air melalui jaringan pengangkut serta mengkonsumsi kandungan sel inang setelah terjadi kontak (Agrios, 1996).

\section{Penilaian Resistensi Klon}

Klon karet memiliki tingkat ketahanan genetik yang berbeda terhadap patogen. Klon yang memiliki ketahanan horizontal dapat memperlambat serangan penyakit (Hadi dan Hartana, 2004). Menurut Hadi (2005), agar ketahanan tanaman karet terhadap penyakit gugur daun dapat berlangsung lebih lama, maka perlu dirakit klon unggul baru yang memiliki ketahanan poligenik (polygenic resistance).

Dari hasil penelitian menunjukkan adanya perbedaan resistensi klon yang diuji terhadap patogen dari C. cassiicola, C. gloeosporioides dan O. heveae. Berdasarkan nilai skala resistensi, maka kelompok klon yang tergolong resisten terhadap $C$. gloeosporioides adalah RRIC 100, moderat resisten (PB 254, PB 260, PB 312, PB 314, PB 340, PB 366, RRIM 911, RRIM 921, RRIC 102), moderat (PB 330, PB 350, PB 359, RRIM 901, RRIM 908, RRIC 110, RRII 105, RRII 176), dan moderat rentan (PB 217, RRIM 937). Tidak ada klon yang diuji tergolong resisten terhadap $O$. Heveae, yang termasuk moderat resisten adalah $\mathrm{PB} 260$, PB 217, PB 254, PB 312, PB 314, PB 350, PB 359, RRIM 908, RRIM 911, RRIM 921, RRIM 937, RRIC 100, RRIC 110, RRII 105, RRII 176, moderat (PB 330, PB 366, RRIM 901, RRIC 102) dan moderat rentan (PB 340). Kelompok klon yang tergolong resisten terhadap C. cassiicola adalah PB 260 dan RRIC 100, moderat resisten (PB 217, PB 254, PB 312, PB 314, PB 330, PB 340, PB 350, PB 366, RRIM 901, RRIM 908, RRIM 921, RRIM 937, RRIC 102, RRIC 110, RRII 105, RRII 176) dan moderat (PB 359, RRIM 911).

Klon RRIC 100 adalah klon yang paling resisten terhadap C. gloeosporioides dan $C$. cassiicola, sedangkan klon PB 260 paling resisten terhadap $C$. cassiicola. Tidak ada klon introduksi yang diuji tergolong rentan terhadap ketiga penyakit gugur daun. Klonklon yang resisten dapat dimanfaatkan 
Tabel 5. Resistensi klon karet yang diuji terhadap penyakit gugur daun Table 5. Resistance of the tested rubber clones to leaf fall diseases

\begin{tabular}{|c|c|c|c|}
\hline \multirow{2}{*}{$\begin{array}{c}\text { Klon } \\
\text { Clones }\end{array}$} & \multicolumn{3}{|c|}{$\begin{array}{l}\text { Nilai resistensi } \\
\text { Resistance rate }\end{array}$} \\
\hline & C. gloeosporioides & O. heveae & C. cassiicola \\
\hline PB 260 & MR & MR & $\mathrm{R}$ \\
\hline PB 217 & MS & MR & MR \\
\hline PB 254 & MR & MR & MR \\
\hline PB 312 & MR & MR & MR \\
\hline PB 314 & MR & MR & MR \\
\hline PB 330 & M & M & MR \\
\hline PB 340 & MR & MS & MR \\
\hline PB 350 & M & MR & MR \\
\hline PB 359 & M & MR & M \\
\hline PB 366 & MR & M & MR \\
\hline RRIM 901 & M & M & MR \\
\hline RRIM 908 & M & MR & MR \\
\hline RRIM 911 & MR & MR & M \\
\hline RRIM 921 & MR & MR & MR \\
\hline RRIM 937 & MS & MR & MR \\
\hline RRIC 100 & $\mathrm{R}$ & MR & $\mathrm{R}$ \\
\hline RRIC 102 & MR & M & MR \\
\hline RRIC 110 & M & MR & MR \\
\hline RRII 105 & M & MR & MR \\
\hline RRII 176 & M & MR & MR \\
\hline $\begin{array}{l}\text { : resiste } \\
: \text { moder } \\
: \text { moder }\end{array}$ & derately resistant) & $\begin{array}{l}\text { moderat rentar } \\
\text { rentan (suscep }\end{array}$ & susceptible) \\
\hline
\end{tabular}

dalam program pemuliaan karet untuk merakit klon unggul penghasil lateks tinggi dan tahan penyakit gugur daun. Nilai resistensi klon terhadap penyakit gugur daun dapat dilihat pada Tabel 5.

Penggunaan klon resisten sebagai tetua dalam persilangan buatan, akan memberikan peluang untuk menghasilkan keturunan (progeny) yang memiliki tingkat resistensi yang tinggi. Karakter potensi hasil lateks diwariskan secara poligenik (poligenic inheritance), sedangkan ketahanan terhadap penyakit umumnya diturunkan dengan gen sederhana (simplegenic inheritance). Salah satu cara yang dapat dilakukan untuk memperoleh klon penghasil lateks tinggi yang tahan penyakit adalah dengan teknik konvensional yaitu menyilangkan tetua karet tahan penyakit daun dengan tetua produksi tinggi secara berulang-ulang, sehingga terdapat peluang untuk menyeleksi progeni yang tahan penyakit dari populasi F1.

\section{KESIMPULAN DAN SARAN}

Hasil pengujian lab berbagai klon karet introduksi terhadap penyakit gugur daun Colletotrichum gloeosporioides, Oidium heveae dan Corynespora cassiicola menunjukkan klon RRIC 100 dan PB 260 memiliki ketahanan yang paling baik terhadap ketiga penyakit gugur daun, menyusul klon yang tergolong moderat resisten yaitu PB 254, PB 312, PB 314 dan RRIM 921. Klon- klon tersebut sangat potensial dimanfaatkan dalam program pemuliaan dan disarankan digunakan sebagai tetua persilangan untuk merakit klon karet unggul baru produksi tinggi dan tahan penyakit gugur daun. 


\section{DAFTAR PUSTAKA}

Aidi-Daslin dan Sayurandi. 2006. Pengaruh interaksi genotipe dan lingkungan terhadap pertumbuhan dan produksi klon IRR seri 100 pada uji lanjutan. Jurnal Penelitian Karet 24(2): 91-100.

Aidi-Daslin, S. Woelan, M. Lasminingsih dan H. Hadi. 2009. Kemajuan pemuliaan dan seleksi tanaman karet di Indonesia. Prosiding Lokakarya Nasional Pemuliaan Tanaman Karet 2009. 4-6 Agustus 2009. Puslit Karet.

Agrios, G.N., 1996. Mmu Penyakit Tumbuhan. Gadjah Mada University Press, Yogyakarta.

Anggreani, H. 1975. Tinjauan mengenai tingkat infeksi secara alami daripada Oidium heveae pada klon GT 1 yang diradiasi. Menara Perkebunan 45 (2).

Chee, K.H. 1988. Corynespora leaf spot Malaysia. Country report Malaysia, Thailand, Sri Lanka and Indonesia. Workshop on leaf spot disease on Hevea Rubber. Februari 12-13, Bogor. Indonesia. p.5.

Hadi, H. 2005. Sifat ketahanan beberapa klon karet terhadap penyakit gugur daun Corynespora. 23(1), 36-46.

Hadi, H. dan A. Hartana. 2004. Analisis penanda molekuler sifat ketahanan tanaman karet terhadap penyakit gugur daun Corynespora. Jurnal Penelitian Karet, 22(2): 47-56.

Kajornchaiakul, P. 1987. Corynespora disease of Hevea in Thailand. Proceeding IRRDB. Symposium Patholosy of Hevea brasiliensis, November 2-3, Chiang May. Thailand. 1- 5 .

Mathew, J. 2006. Clonal resistance of Hevea brasiliensis to corynespora leaf fall disease. Corynespora leaf fall disease of Hevea brasiliensis strategies for management. Rubber Research Institute of India. Kottayam. India, 8396.
Newsam, A. 1961. Pathological Division. Annual Report of Rubber Research Institute of Malaysia, 63-70.

Othman, R., M. Benong, Ong, S.H. and I. Hashim. 1996. Strategies and development of resistant Hevea clones againts Corynespora leaf fall. Pros. Corynespora leaf fall disease of Hevea rubber. Medan 16-17 December 1996, 177-193.

Pawirosoemardjo, S. 1999. Laporan hasil penelitian epidemiologi dan pengendalian penyakit gugur daun Corynespora dan Colletotrichum secara terpadu. Proyek Penelitian Karet Sungei Putih, 5p.

Pawirosoemardjo, S. Syafiuddin dan Sujatno. 1998. Resistensi klon harapan terhadap penyakit utama tanaman karet. Lokakarya Nasional Pemuliaan Karet 1998 dan Diskusi Nasional Prospek Karet dalam abad 21. Medan, 8-9 Desember 1998. 223-235,

Pawirosoemardjo, S. 2004. Managemen pengendalian penyakit penting dalam upaya mengamankan target produksi karet nasional tahun 2020. Pertemuan Teknis Strategi Pengelolaan Penyakit Tanaman Karet untuk Mempertahankan Potensi Produksi Mendukung Industri Perkaretan Indonesia Tahun 2020 di Palembang, 6-7 Oktober . Balit Sembawa. 17p.

Pawirosoemardjo, S. dan H. Suryaningtyas. 2008. Strategi pengendalian penyakit gugur daun dan pencegahan penyakit hawar daun Amerika Selatan pada tanaman karet di Indonesia. Prosiding Lokakarya Nasional Agribisnis Karet 2008. Yogyakarta 20-21 Agustus. 194212.

Ramakrishnan, T.S. and Pillay, N.R. 1961. Leaf spot of rubber caused by Corynespora cassiicola (Berk \& Curt.) Wei. Rubber Board Bulletin, 5(1): 32 35 .

Simmonds, N.W. 1989. Rubber Breeding. In Webster CC, Baulkwill WJ (ed). Rubber. New York, Longman Scientific and Technical. 
Situmorang, A., A. Budiman, S.
Pawirosoemardjo dan M. $\mathrm{P}$ a wiroso e m a r j o d a $\mathrm{n}$ M .
Lasminingsih. 1996. Epidemic of corynespora leaf fall disease and its preventive methods in rubber plantation. Proceedings CLF Disease of Hevea Rubber Medan, 16-17 Dec . Pusat Penelitian Karet. p 260.
Soepena, H. 1983. Gugur daun Corynespora pada tanaman karet di Sumatera Utara. Balai Penelitian Sungei Putih. 